\title{
PHYSIOLOGICAL-HYGIENIC STANDARDS OF MOTOR ACTIVITY OF STUDENTS OF HIGHER EDUCATION INSTITUTIONS AND SCIENTIFIC SUBSTANTIATION OF WAYS OPTIMIZATION IN THE CONTEXT OF FORMATION OF EFFECTIVE PUBLIC HEALTH SYSTEM
}

DOI: 10.36740/WLek202005108

\author{
Ihor V. Serheta, Olha P. Mostova, Olexander Y. Panchuk, Inna L. Drezhenkova \\ NATIONAL PIROGOV MEMORIAL MEDICAL UNIVERSITY, VINNYTSIA, UKRAINE
}

\begin{abstract}
The aim: Scientific substantiation of physiological-hygienic standards of motor activity of students of higher education institutions and ways of its optimization in the context of formation of an effective public health system.

Materials and methods: The criteria for physiological-hygienic assessment of students' motor activity were: the values of daily energy, the quantity of locomotions, the duration of dynamic component in daily budget of time.

Results: The data of complex assessment of the modern students' motor activity studying in the institution of higher medical education showed its low level. At the same time the application of measures aimed at optimizing motor activity of students ensured an improvement $(p<0.01-0.001)$ of the functional characteristics of the mobility and balance of nervous processes and index of coordination of movements.

Conclusions: In the course of the researches the physiological-hygienic standards of motor activity of students are scientifically substantiated: values of daily energy consumption -9000-11000 kJ in young women, 11500-13500 kJ in young men, the quantity of locomotions in the daily cycle - 14000-18000 steps and 15000-19000 steps respectively, the duration of dynamic component in daily budget of time - 130-180 min and 140-190 min respectively.
\end{abstract}

KEY WORDS: students, motor activity, standards, ways to optimize, public health

Wiad Lek. 2020;73(5):877-882

\section{INTRODUCTION}

Considering the changes in approaches to health policy making for different categories of population, including the health of students youth, which are occurring in the current context, it should be noted that in a number of legislative, regulatory and regulatory documents and scientific developments, defining global trends for the preservation and promotion of health, both of individual members of the public and of the general population, in particular in the WHO Health for All Strategy in the 21st Century, the guiding principles of the European Union's "Health Policy 2020: the basics of European policy in support of the actions of the state and society in the interests of health and well-being", the national strategy for health promotion activity in Ukraine for the period up to 2025: "Motor activity - healthy lifestyle - healthy nation", etc., as priority goals are defined: development of scientific bases of healthy way of life of student youth, substantiation and introduction in activity of higher education institutions of effective and adequate requirements of present preventive technologies, substantiation of recommendations on organization of improving motor activity (MA) to promote the health of students, the implementation of an effective system for monitoring the criteria of MA $[1,2,3,4,5,6]$.
These provisions are extremely important, also because the health of students, first of all, is determined by the level of functionality and adaptive resources of their organism, which depends on the level of habitual MA - an integral component of her lifestyle and a sign of the implementation of individual behavioral actions and depends on the peculiarities of the organization of daily activities, morphofunctional features of the organism, motivation for physical education $[7,8,9,10,11,12,13,14]$.

Therefore, MA as an extremely important category of modern preventive medicine, criterion in character and health-giving in its content characteristics of the level of adaptation and functionality of the human organism, is determined by a certain total quantity of locomotions (movements), which a particular person performs time interval, or throughout your life. As its main components in the context of solving health problems of student youth, it is customary to allocate MA during the performance of educational activity, MA in the process of physical education and spontaneous MA during leisure time $[15,16,17,18,19,20]$.

\section{THE AIM}

The purpose of the research is to substantiate the physiological-hygienic standards of motor activity students of 
higher education institutions and ways of its optimization in the context of the formation of an effective public health system.

\section{MATERIALS AND METHODS}

The research, which centered on 385 students, including 200 young women and 185 young men, aged 19 to 21 , was conducted at National Pirogov Memorial Medical University, Vinnytsya. The methodological basis of the scientific work was carried out fully corresponded to requirements of the current legislation, the international standards and the existing bioethical standards, which was confirmed by the conclusion of the University Bioethics Committee.

Thus, as criteria for implementation of complex physiological-hygienic assessment of MA of student youth were used: the values of daily energy consumption, the quantity of locomotions, the duration of dynamic component in daily budget of time. The energy consumption during the day were calculated by the time-table method. The quantity of locomotions in the daily cycle was determined based of the use of standard digital pedometers: SIGETA PMT-01, Pedometr G014, I-PDM 2002. The duration of dynamic component in daily time budget was determined on the basis of careful timing of the main types of educational and extracurricular activities.

An in-depth assessment of the peculiarities of the regime of the day, adaptive capacity of the student, and the medical, social and housing conditions of their lives, depending on the level of MA, was conducted on the basis of questionnaires. For the assessment of health indicators of young women and men, morbidity indicators with temporary disability and chronic morbidity and results of subjective assessment by students of their own health were used.

In order to perform a generalized assessment of the level of development of psychophysiological functions, indicators of higher nervous activity were evaluated on the basis of determining the magnitudes of latent periods of simple and differentiated visual-motor reactions, mobility and balance of nervous processes using the method of chronoreflexometry, were established by estimating the values of the critical fusion frequency of light flashes based on the technique of "Svitlotest", coordination of movements using tremometry, sustained attention and mental capacity was determined using the Schulte special tables.

The data obtained were subject to statistical processing using descriptive statistics and correlation analysis procedures based on the use of the standard statistical analysis software package "Statistica 6.1" (license number BXXR901E245722FA).

\section{RESULTS}

In the course of physiological-hygienic assessment of daily energy consumption of students, using the time-table method, it was found that their average values were $10246.55 \pm 144.45 \mathrm{~kJ}$ among young women and $12902.93 \pm 246.30 \mathrm{~kJ}$ among young men $(\mathrm{p}<0.001)$. At the same time, while determining the structural features of the distribution of daily MA values of students, it was found that the daily energy consumption in the range from 10000 to $11000 \mathrm{~kJ}(22.3 \%)$ was considered to be the most significant according to the degree of distribution in the student environment. up to $10000 \mathrm{~kJ}(21.2 \%)$ and in the range of 8000 to $9000 \mathrm{~kJ}$ (19.2\%), among young men - daily energy consumption in the range of 10000 to $11000 \mathrm{~kJ}$ (16.2\%), in the range of 13000 to $14000 \mathrm{~kJ}(14.8 \%)$ and in the range of 11000 to $12000 \mathrm{~kJ}(13.4 \%)$. It is very interesting to recognize the data that characterize the fluctuations in the values of the studied indicators in the daily cycle. For both young women and men, the highest rates of daily energy consumption was observed on Monday, the lowest - on Sunday.

During the determination and subsequent physiological-hygienic assessment of the locomotions of students in the daily cycle based on the use of the pedometer technique, it was found that their mean values were $16138.34 \pm 306.05$ steps among young women and $17468.56 \pm 329.94$ steps among young men $(p<0.001)$. Considering the data that determine the peculiarities of fluctuations in the values of the studied indicators in the daily cycle, it should be noted that, as in the case of estimation of daily energy consumption, both young women and men had the highest indicators of locomotor activity on Monday, the lowest - on Sunday.

Shifts in the weekly cycle of indicators that noted results on the duration of the dynamic component in the daily time budget should be considered as similar. According to the data obtained during the determination of the values of the duration of the dynamic component in the daily budget of student time, their mean values were found to be $164.95 \pm 3.54 \mathrm{~min}$ for young women and $164.95 \pm 3.54$ min for young men ( $>0.05)$. Very interesting information is provided by the data on estimation of values of the studied indicators, which characterize the peculiarities of their fluctuations in the daily cycle. For both young women and men, the highest values of the duration of the dynamic component was observed on Monday, the lowest - on Sunday.

Thus, the data obtained during the determination of the peculiarities of the values of the dynamic component in daily budget of students' time and the quantity of student locomotions per week cycle, supported the general patterns that were found in determining the values of daily energy consumption, although determining the variability of the study values were sufficiently identical to the changes that took place in the dynamics of the week by the daily energy consumption figures of young women and men and, most importantly, convincingly attested to them low enough.

The results of the conducted researches clearly and adequately determine the fact that for further research in order to substantiate the values of MA students, it is necessary, to use the objective criterion for determining the characteristics of MA of young women and men, which is not influenced as external and internal factors and is noted by the absence of pronounced individually-conditioned differences during the weekly cycle, namely the magnitude 
of daily energy expenditure in the duty interdependence of a number of other criteria, which are metrics locomotions daily budget in time duration and value of the dynamic component in the daily budget time. Secondly, given the peculiarities of different levels of MA, students should subsequently be divided into three comparison groups, to which persons with low (1 group), medium (2 group) and high (3 group) MA levels should be involved. As such, daily energy consumption rates of up to $9000 \mathrm{~kJ}$ (low MA), 9000-11000 kJ (average MA) and over $11000 \mathrm{~kJ}$ (high MA) - among young women, and MA up to 11000 kJ (low MA), 11,000-13500 kJ (average MA) and over $13500 \mathrm{~kJ}$ (high MA) - among young men. Finally, third, an integral part of research aimed at establishing the criteria values of MA students should be considered to determine the peculiarities of the processes of formation of indicators of psychophysiological adaptation to the conditions of performing educational and extracurricular activities in the institution of higher medical education, individual psychophysiological functions of the students organism in natural and preformed conditions.

In implementing the approaches defined above, it was necessary to emphasize that during the assessment of the peculiarities of the daily energy consumption of students who were assigned to group 1 of MA, it was found that their values were $8262,78 \pm 73,45 \mathrm{~kJ}$ among young women and $12902,93 \pm 246.30 \mathrm{~kJ}$ among young men $(\mathrm{p}<0.001)$, magnitudes of students' locomotions in the weekly cycle $-12224.73 \pm 77.63$ steps among young women and $13478.76 \pm 107.68$ steps among young men $(p<0.001)$, values of indicators the duration of dynamic component in daily time budget was $113.42 \pm 0.42 \mathrm{~min}$ for young women and $116.44 \pm 0.65 \mathrm{~min}$ for young men $(\mathrm{p}<0.001)$. The most significant prevalence in the student environment was considered to be the daily energy consumption in range from 8500 to $9000 \mathrm{~kJ}(40.0 \%)$ and in range from 8000 to $8500 \mathrm{~kJ}(32.0 \%)$ among young women and in range from 10000 to $10500 \mathrm{~kJ}(26.7 \%)$ and in range from 10500 to $11000 \mathrm{~kJ}(24.4 \%)$ - among young men.

During the physiological-hygienic assessment of the peculiarities of the daily energy consumption of students who were assigned to group 2 of MA, their values were found to be $9948.31 \pm 87.32 \mathrm{~kJ}$ among young women and $12353.96 \pm 109.82 \mathrm{~kJ}$ among young men $(\mathrm{p}<0.001)$, the magnitudes of student' locomotions in the weekly cycle $-16416,02 \pm 66,66$ steps among young women and $17350,69 \pm 87,21$ steps among young men $(p<0,001)$, the values of indicators of the duration of dynamic component in daily budget of time $-162,25 \pm 0.34 \mathrm{~min}$ for young women and $165.88 \pm 0.58 \mathrm{~min}$ for young men $(\mathrm{p}<0.001)$. In assessing the structural features of the distribution of daily MA values of young women the daily energy consumption was in range from 9000 to $9500 \mathrm{~kJ}(34.0 \%)$ and in range from 10000 to $10500 \mathrm{~kJ}(30.0 \%)$, among young men - in range from 13000 to $13500 \mathrm{~kJ}(28.8 \%)$ and in range from 11500 to $12000 \mathrm{~kJ}(26.7 \%)$.

Finally, in determining the features of the daily energy consumption of students who were assigned to group 3 of
MA, it was found that their values were $12534.20 \pm 165.63$ $\mathrm{kJ}$ among young women and $15419.45 \pm 198.43 \mathrm{~kJ}$ among young men $(\mathrm{p}<0.001)$, the magnitudes of students' locomotions in the weekly cycle $-19774,28 \pm 86,76$ steps among young women and $21576,24 \pm 122,21$ steps among young men $(p<0,001)$, the values of indicators of the duration of dynamic component in daily budget of time $-219,17 \pm 0.38$ min for young women and $230.27 \pm 0.55 \mathrm{~min}$ for young men $(p<0.001)$. The most significant prevalence among young women was considered to be the daily energy consumption in range from 11500 to $12000 \mathrm{~kJ}(26.0 \%)$ and in range from 13000 to $13500 \mathrm{~kJ}$ (24.0\%), among young men the daily energy consumption within the limits over $15500 \mathrm{~kJ}$ (26.7\%), in range from 13500 to $14000 \mathrm{~kJ}(17.8 \%)$ and in range from 15000 to $15500 \mathrm{~kJ}(17.8 \%)$.

Considering the peculiarities of MA in the daily cycle according to the level of daily energy consumption, it was necessary to note the fact that their structure for students of 1 and 2 MA groups was quite similar to the general characteristic of the studied students in general. The highest level of MA among young women was typical for such days of the week as Monday, Wednesday and Friday, the lowest levels of MA - for days of the week such as Sunday, Tuesday and Saturday, the highest levels of MA among young men were characteristic of such days of the week as Monday, Wednesday and Tuesday, the lowest levels of MA - for days of the week such as Sunday, Friday and Saturday.

The structural features of MA in the daily cycle in students of group 3 of MA had a different character. The highest levels of MA among young women were typical for such days of the week as Saturday, Monday and Tuesday, the lowest levels of MA - for such days of the week as Sunday, Wednesday and Thursday, at the same time the highest level. MA among young men was characteristic of such days of the week as Monday, Saturday and Tuesday, the lowest level of MA - for days of the week such as Sunday, Friday and Thursday, that is, among young women and representatives of this group significantly increased the level of MA over the weekend as well as the first days of the week.

Almost similar to the previous one should recognize the structural features of the distribution of MA according to the generalized values of locomotor activity and the duration of dynamic component in daily budget - for both young women and men, the highest indicators of the duration of the dynamic component were registered on Monday, the lowest - on Sunday.

The data of correlation analysis testified to the fact that the highest number of correlation between the investigated indicators of psychophysiological functions and leading characteristics of the state of health, adaptive posibilities of the organism and the level of academic performance in adolescents belonging to group 2 of MA (daily energy consumption levels $9000-11000 \mathrm{~kJ}$ in young women and $11000-13500 \mathrm{~kJ}$ in young men), corresponding to the existing most positive effect on the processes of formation is an organization of MA.

Taking into account the peculiarities of the processes of professional formation of future specialists in the medical 
Table I. Physiological-hygienic standards of motor activity of modern students

\begin{tabular}{cc}
\hline Sex & Physiological-hygienic standards of motor activity \\
\hline Young women & According to the level of daily energy consumption, $\mathrm{kJ}$ \\
\hline Young men & $9000-11000$ \\
\hline Young women & $11000-13500$ \\
\hline Young men & According to the quantity of locomotions in the daily cycle, steps \\
\hline & $9000-11000$ \\
\hline Young women & According to the duration of dynamic component in daily time budget, min \\
\hline Young men & $130-180$ \\
\hline
\end{tabular}

profile, associated with the need to absorb large volumes of theoretically and practically meaningful information, this situation testified to the existence of clearly expressed signs of a positive influence of the motor regime, which is peculiar for students group 2 of MA, which contributed to the predominant development of the leading characteristics of the higher nervous activity of the young women and men who studied.

The obtained results make it possible to scientifically substantiate the physiological-hygienic standards of MA students, taking into account the peculiarities of social and professional growth of future specialists and have a favorable influence on the processes of health formation and adaptive capacity of their organism (Table I).

Results of physiological-hygienic assessment of the effectiveness of influence on the functionality of the organism of young women and men complex activities aimed at rational organization of MA of modern students, the leading stages of practical implementation of which were the following stages: stage 1 - physiological-hygienic assessment of the level of habitual MA on the basis of determining of daily energy consumption, the quantity of locomotions in the daily cycle and the duration of dynamic component in daily budget of time and increasing their significance to the scientifically substantiated values; stage 2 - introduction the rational organization of students' daily MA by optimizing the basic regime elements with existing regulatory approaches; stage 3 - the use of separate exercises of the proposed measures, namely: exercises of morning hygienic and evening hygienic gymnastics, walking and jogging, visual and breathing exercises, showed the appearance of positive results.

The obtained data determined that the most positive impact of the developed of measures had on the characteristics of psychophysiological functions: mobility and balance of nervous processes, coordination of movements too. The complex activities provided an improvement $(\mathrm{p}<0.01-0.001)$ of the functional characteristics of the mobility of the nervous processes by $59.5 \%$ in young women and $44.0 \%$ in young men, the characteristics of balance of the nervous processes - by $25.4 \%$ in young women and $26.5 \%$ in young men, indicators of the number of touches during tremor - by $17.2 \%$ in young women and $22.6 \%$ in young men, indicators of the integral index of coordination of movements - by $16.4 \%$ in young women and $22.3 \%$ of young men.

Somewhat less pronounced impact of the complex was noted in the case of physiological-hygienic assessment of such psychophysiological functions $(\mathrm{p}<0.05-0.001)$, as the speed of simple and differentiated visual-motor response, as well as performance indicators of the work performed. Thus, the use of the developed complex reduced the latent period of simple visual-motor reaction by $13.1 \%$ in young women and $11.9 \%$ in young men, reduced the latent period of the differential visual-motor reaction by $10.6 \%$ in young women and $11,1 \%$ for young men, performance indicators $-13.1 \%$ for young women and $10.6 \%$ for young men.

The least significant positive impact of measures aimed at rational organization of MA of modern students, which was introduced, was peculiar to the characteristics of such psychophysiological functions as the functional posibilities of the visual sensory system and indicators of the degree of involvement and mental endurance. The use of developed complex provided an improvement in the functional characteristics of the critical fusion frequency of light flashes by $3.2 \%$ in young women and by $5.1 \%$ in young men, indicators of the degree of involvement in the activity performed - by $2.0 \%$ in young women, indicators of mental endurance - by $2.0 \%$ for young men.

\section{DISCUSSION}

Considering the results obtained and, above all, the data on the magnitudes of energy consumption and the number of locomotions of students in the daily cycle, as well as the duration of the dynamic component in the daily budget of time, first of all, it should be noted that the level of MA of young women and men, who undertake intensive training in higher education institutions are low. This fact coincides with the data obtained in a number of studies conducted in recent years in educational institutions of different profiles $[9,10,11,12]$, and apparently due to the peculiarities of the construction of the regime of the day, above all, the high intensity of mental and other workloads, peculiar to modern students.

Also noteworthy is the fact that when analyzing data that note patterns of fluctuations in MA values in the daily 
cycle among young women and men, their most significant values are observed on the day of the week, such as Monday, the least significant - on such a day of the week as Sunday. The similar nature of the distribution of MA indicators differs significantly from the characteristics inherent in the similar characteristics of the organism of schoolchildren and students established in scientific research conducted during the last decades of the twentieth century $[1,15,16,19]$. Even 20 years ago, the trainees were characterized by structural characteristics of the distribution of the leading characteristics of the MA of the reverse content, namely: a decrease in the level of MA on school days and a marked increase in MA indicators on weekends and holidays.

The aforementioned situation and, above all, significant changes in the stereotype of daily activities related to the pronounced increase in the specific weight of passive forms of its organization, shows the indispensable need both in substantiation of physiological and hygienic standards of MA students of higher education institutions, established and in the development of aimed at ensuring rational organization of MA of young women and men and identifying leading ways of optimization of MA for modern student youth. As such it should be noted: implementation of continuous monitoring and individualized complex physiological and hygienic assessment of habitual MA of students on the basis of determining the values of daily energy consumption, the number of locomotions and the duration of the dynamic component in the daily budget of time; taking into account the physiological and hygiene standards of MA student youth, which provide a significant beneficial influence on the processes of formation of the state of health and adaptive capacity of the organism of future specialists and the mandatory achievement of their values in the process of organizing the educational process in institutions of higher education and during the extracurricular activities of young women and men; scientific substantiation and introduction of preventive-conditioned strategies of organization of daily activity, developed taking into account the values of physiological and hygienic standards of MA student youth and a set of measures aimed at optimization and rational organization of MA of modern students.

Finally, the analysis of the data of modern scientific literature $[2,3,4,7,12,18]$, as well as the results obtained during the study and, in particular, the data on determining the degree of effectiveness of the impact on the functionality of the organism of young women and men complex activities aimed at on the optimization and rational organization of MA of modern students, emphasizes that the main stages of practical implementation of measures of this direction should be the steps to assess the level of habitual MA young women and men and increase its magnitude values to scientifically based, efficient organization of students daily through the optimization of the main operational elements using exercises morning gymnastics hygienic and evening relaxation exercises, of walking and running exercises, breathing exercises too.

\section{CONCLUSIONS}

1. The data of complex physiological-hygienic assessment of the habitual motor activity of modern student youth studying in the institution of higher medical education, conducted on the basis of determining the magnitudes of daily energy consumption, the quantity of locomotions of students in the daily cycle and the duration of dynamic component in daily budget, convincingly low.

2. Scientifically substantiated physiological-hygienic standards of motor activity of students of higher educational institutions, taking into account the peculiarities of social formation and professional growth of future specialists and providing the most significant beneficial influence on the processes of formation of a state of health and the adaptive capacity of their organism: values of daily energy in young women and $11500-13500 \mathrm{~kJ}$ in young men, the quantity of locomotions in the daily cycle - 14000-18000 steps in young women and 15000-19000 steps in young men; the duration of dynamic component in daily time budget - 130-180 min for young women and 140-190 min for young men.

3. It is established that among the main ways to optimization the motor activity of student youth should include: the implementation of constant monitoring and individualized complex physiological-hygienic assessment of students' habitual motor activity based on determining the values of daily energy consumption, the quantity of locomotions and the duration of dynamic component; taking into account hygienic standards of motor activity of student youth, which provide significant favorable influence on the processes of forming the state of health and adaptive capacity of the organism of future specialists and obligatory achievement of their values in the course of organizing the educational process in higher educational establishments and during the extracurricular activities of young women and men; scientific substantiation and introduction of preventively conditioned strategies of organization of daily educational and extracurricular activities, developed taking into account the values of physiological-hygienic standards of motor activity of students and a set of measures aimed at optimization of motor activity and rational organization of motor activity of modern student youth.

\section{REFERENCES}

1. Physical activity and health in Europe: evidence for action; ed. by N. Cavill, S. Kahlmeier, F. Racioppi. Copenhagen: WHO Regional Office for Europe. 2006; 34.

2. Cale L., Harris J. Interventions to promote young people's physical activity - issues, implications and recommendations for practice. Health Education Journal. 2006; 65(4):320-337.

3. Steps to health. A European framework to promote physical activity for health. Copenhagen: WHO Regional Office for Europe. 2007; 45.

4. Global recommendations on physical activity for health. Geneva: World Health Organization. 2010, 57.

5. Kohl H.W., Murray T. D. Foundation of Physical Activity and Public Health. Champaing: Human Kinetics. 2012; 281.

6. Physical activity strategy for the WHO Europen Region 2016-2025. Copenhagen: WHO Regional Office for Europe. 2015; 27. 
7. Bar-Or 0., Rouland T. Zdorove detej i dvigatelnaya aktivnost: ot fiziologicheskih osnov do prakticheskogo primeneniya [Children's health and physical activity: from physiological foundations to practical use]. Kiev: Olimpijskaya literature. 2009; 528. (Ru)

8. KeeleyT.J.H., FoxK. R. The impact of physical activity and fitness on academic achievement and cognitive performance in children. International Review of Sport and Exercise Psychology. 2009; 2(2):198-214.

9. Hozak S. V., Yelizarova 0. T., Stankevych T. V. Osoblyvosti rozumovoi pratsezdatnosti uchniv zalezhno vid osoblyvostei yikhnoho zdorovia u zahalnoosvitnikh navchalnykh zakladakh zriznoiu orhanizatsiieiu fizychnoho vykhovannia [Peculiarities of the mental capacity of students depending on the peculiarities of their health in secondary schools with a variety of physical education organization]. Naukovyi chasopys NPU. Seriia № 15. 2011; 10:188-192. (UA)

10. Serheta I. V., Bratkova 0. Y., Mostova 0. P. i in. Naukovi printsipi psihogigienichnoyi diagnostiki stanu zdorov'ya ditey, pidlitklv ta molodi [Scientific principles of psychohygienic diagnostics of the health of children, adolescents and youth]. Dovkillya ta zdorov'ya. 2012; 4(64):21-25. (UA)

11. Futornyj C. M. Problema deficita dvigatelnoj aktivnosti studencheskoj molodezhi [The problem of lack of motor activity of student youth]. Fizicheskoe vospitanie studentov. 2013; 3: 75-79. (Ru)

12. Serheta I. V., Panchuk 0. Y., Stoian N. V. i in. Universytetska hihiiena u konteksti implementatsii "Zakonu pro vyshchu osvitu": fizioloho-hihiienichni osnovy, realii ta shliakhy rozvytku [University hygiene in the context of implementation of the "Law on Higher Education": physiological and hygiene foundations, realities and ways of development]. Dovkillia ta zdorovia. 2016; 4(80):46-52. doi. org/10.32402/dovkil2019.04.030. (UA)

13. Serheta I. V., Makarov S. Y., Serebrennikova 0. A. Navchalnyi stres u studentiv suchasnykh zakladiv vyshchoi medychnoi osvity: psykhofiziolohichni kryterii diahnostyky ta psykhohihiienichnoi korektsii [ducational stress in students of modern institutions of higher medical education: psychophysiological criteria of diagnostics and psychohygienic correction]. Dovkillia ta zdorovia. 2019; 4(93):30-37. doi. org/10.32402/dovkil2019.04.030. (UA)

14. Makarov S. Y., Stoyan N. V., Serheta I. V. et al. Peculiarities of the interaction of the indicatiors of psychophysiological adaptation of modern students in the context of the effective monitoring of individual health of young women and young men. Wiadomości Lekarskie. 2019;:LXXII.5.I:1053-1058.

15. Suharev A. G.Zdorove i fizicheskoe vospitanie detej i podrostkov [Health and physical education of children and adolescents]. Moskva; Medicina. 1991; 272. (Ru)

16. Serheta I. V., Bardov V. H. Orhanizatsiia vilnoho chasu ta zdorovia shkoliariv [Organization of leisure time and health of pupils]. Vinnytsia: RVV VAT “Vinobldrukarnia”. 1997; 292. (UA)

17. Sallis J. F., Johnson M. F., Calfas K. J. et al. Assessing Perceived Physical Environmental Variables that May Influence Physical Activity. Research Quarterly for Exercise and Sport. 1997;68(4):345-351. doi:10.1080/02 701367.1997.10608015.

18. Flora P. K., Faulkner G. E. J. Physical Activity. Journal of Intergenerational Relationships. 2007; 4(4):63-74. doi:10.1300/J194v04n04_05.
19. Suharev A. G. Ignatova L. F. Metodologiya izucheniya obrazovatelnoj sredy izdorovya uchashihsya. Gigiena detej i podrostkov: istoriya i sovremennost (problemy i puti resheniya) [Methodology for studying the educational environment and the health of students. Hygiene of children and adolescents: history and modernity (problems and solutions)]. Moskva: Nauchnyj centr zdorovya detej RAMN. 2009; 438. (Ru)

20. Kagotho N. A. Longitudinal Analysis of Physical Activity among Foreignborn Individuals. Journal of Human Behavior in the Social Environment. 2011; 21(5):540-554. doi:10.1080/10911359.2011.580243.

The article was carried out within the framework of the research work: "Development of modern methods of assessment and forecasting the health of children, adolescents and young women and men and the scientific substantiation of the psychophysiological and psychohygienic correction of the functional state, personality traits, adaptive capacity and professional suitability of pupils and students" (State registration number 0116U000038) and "Physiological-hygienic assessment of the characteristics of adaptation of children, adolescents and young people to the conditions of study in modern educational institutions and the scientific bases of university hygiene: vocational guidance, problems of introduction of health-saving technologies and creation of preventive educational environment" (State registration number 0116U0000).

\section{ORCID and contributionship:}

Ihor $V$. Serheta - 0000-0002-4439-3833 ${ }^{A, F}$

Olha P. Mostova - 0000-0001-8249-6748 D,E

Olexander Y. Panchuk - 0000-0002-8996-9314 D,E

Inna L. Drezhenkova - 0000-0002-6794-2516 B,C,D

\section{Conflict of interest:}

The Authors declare no conflict of interest

\section{CORRESPONDING AUTHOR \\ Ihor V. Serheta}

Department of General Hygiene and Ecology, National Pirogov Memorial Medical University, Pirogov str., 56, 21018, Vinnytsia, Ukraine tel: +380501807005

e-mail: serheta@ukr.net, serheta@gmail.com

Received: 26.01 .2020
Accepted: 01.04 .2020

A - Work concept and design, B - Data collection and analysis, C - Responsibility for statistical analysis, D-Writing the article, $\mathbf{E}$-Critical review, $\mathbf{F}$ - Final approval of the article 